\title{
THE EFFECTS OF DIFFERENT TEMPERATURES ON THE BIOSYNTHESIS OF GRAIN PROTEIN IN RICE AT FILLING STAGE
}

\author{
LUO, H. W. ${ }^{1,2 \# *}-$ WANG, Z. M. ${ }^{3 \#}-$ CHEN, Y. Y. ${ }^{1,2 \#}-$ ZHENG, A. X. ${ }^{1}-$ CHEN, Y. L. ${ }^{1}-$ DU, P. ${ }^{3}-$ \\ MAO, T. ${ }^{3}-$ MENG, S. B. ${ }^{3}-$ TANG, X. R. ${ }^{1,2^{*}}$ \\ ${ }^{I}$ Department of Crop Science and Technology, College of Agriculture, South China Agricultural \\ University, 510642 Guangzhou, P.R. China
}

${ }^{2}$ Scientific Observing and Experimental Station of Crop Cultivation in South China, Ministry of Agriculture, 510642 Guangzhou, P.R. China

${ }^{3}$ Key Laboratory of Key Technology for South Agricultural Machine and Equipment, Ministry of Education, 510642 Guangzhou, P.R. China

${ }^{\#}$ These authors have contributed equally to this work.

*Corresponding authors

e-mail: tangxr@scau.edu.cn; phonelfax: +20-8528-0204-618

(Received 23 $3^{\text {rd }}$ Aug 2018; accepted $11^{\text {th }}$ Oct 2018)

\begin{abstract}
Temperature is an important factor which significantly affects rice growth and development. In order to examine the effect of different temperatures at filling stage on grain protein synthesis and accumulation, present study with three different treatments day-night temperature dynamics was carried out in a randomized complete block design with five replications in Experimental Research Farm, College of Agriculture, South China Agricultural University, Guangzhou, China. Treatments included Te1: $33 / 27^{\circ} \mathrm{C}, \mathrm{Te} 2: 28 / 22{ }^{\circ} \mathrm{C}, \mathrm{Te} 3$ : $23 / 17^{\circ} \mathrm{C}$ under $1300 \mathrm{X}$ yellow light intensity and $75 \%$ humidity respectively. Result showed that $\mathrm{Te} 2$ and $\mathrm{Te} 3$ enhanced the activity of glutamic oxalacetic transaminase (GOT) and glutamic-pyruvic transaminase (GPT) in grain in middle and later phase of filling stage while the soluble protein and crude protein in grain were higher in Te3 and Te2 compared with Te1. Furthermore, there were also some differences in activities of glutamine synthelase (GS), glutamate synthetase (GOGAT) and glutamate dehydrogenase (GDH) under different controlled temperature treatments while we observed that grain protein had significant correlation with the activities of GOT, GS and GDH. In general, we considered Te2 as the optimum conditions for rice at filling stage because it enhanced the grain protein content while having the highest yield. We also suggested that in the rice production, we could take some strategies such as delayed sowing date to appropriately lower the temperature at filling stage so the grain protein content could be improved.
\end{abstract}

Keywords: rice, protein content, enzymes, nitrogen metabolism in grain, temperature

\section{Introduction}

Temperature is the main driver of climate change which affects global food production. However, in spite of the challenges faced due to changing climate, global food production needs to increase by about $70 \%$ by 2050 , to feed the growing population (Alam et al., 2012). As one of the most important cereals, rice is feeding more than 3 billion people globally and contributes to the total calorie intake of humans by about $20 \%$. It is also mainly produced and consumed in Asia where it accounts for up to $80 \%$ of the caloric requirement (Mahajan et al., 2010). Just like other crops, rice has its own suitable temperature scopes of every development stages. A previous study (Nguyen, 2005) revealed the minimum and maximum critical temperature ranges of each growth stage for rice are: germination $\left(16-45^{\circ} \mathrm{C}\right)$, seedling rise $\left(12-35^{\circ} \mathrm{C}\right)$, rooting $\left(16-35^{\circ} \mathrm{C}\right)$, tailoring $(9-$ $\left.33^{\circ} \mathrm{C}\right)$, panicle heading $\left(15-30^{\circ} \mathrm{C}\right)$, anthesis $\left(22-35^{\circ} \mathrm{C}\right)$ and ripening $\left(12-30{ }^{\circ} \mathrm{C}\right)$. Kong et 
al. (2017) also demonstrated that the optimal temperature ranges between heading and physiological maturity is $27-30^{\circ} \mathrm{C}$. Further, an early study suggested that yields of doubleseason early rice are more vulnerable to heat stress at post-heading stages (such as grain filling) than single-season rice while emphasizing to develop some management strategies to stabilize rice production in south China under high temperature stress (Shi et al., 2015).

As one of the important components of rice, grain protein content has a direct impact on rice quality. How to improve rice protein content and nutrition quality has been paid attention by many researchers (Samonte et al., 2006) and there have been many researches which using artificial climate box temperature control or field different planting season and other tests to study the grain-filling dynamic under the different temperature treatment including system analysis sucrose, starch granule structure change unloading and key enzymes of starch synthesis way (Yamakawa and Hakata, 2010; Yamakawa et al., 2007; Umemoto et al., 2015). For example, high temperature $\left(35 / 30{ }^{\circ} \mathrm{C}\right.$, day/night) during the grain filling decreased the accumulation of globulin but increased that of glyoxalase I and peroxiredoxin (Lin et al., 2010). The study of Zhong et al. (2010) revealed in early season, the high temperature in grain filling stage was able to decrease eating and cooking quality of rice. Moreover, an early research also demonstrated that high temperature at filling stage could increase the rates of grain filling and leaf senescence while reducing the durations. However, grain filling was terminated earlier than complete leaf senescence, the time gap being greater at higher temperature (Kim et al., 2011).

In spite of plenty of studies about grain filling, the nitrogen metabolism in rice grain grouting process under different temperature treatments of key enzymes involved in the activity type, associated with gene expression changes and the relationship between grain nitrogen assimilation, storage protein accumulation, there is a lack of a clear understanding. Physiological and biochemical studies on plant nitrogen metabolism showed that inorganic nitrogen in higher plant leaves and other organs is transported to grain in the form of amino acids and amides, and then protein was synthesized in grain (Lea, 1999). For example, in grain, glutamine synthetase (GS) could generate glutamine by catalytic glutamate and ammonia $\left(\mathrm{NH}_{3}\right)$ under ATP energy, and through the glutamine synthetase/glutamate synthetase (GS/GOGAT) cycle catalytic alpha ketone glutaric acid and glutamine transaminase to regulate the production of glutamate, between in the metabolism of inorganic nitrogen into organic nitrogen link plays a key role, then, Glutamic-oxaloacetic transaminase (GOT) and Glutamic-pyruvic transaminase (GPT) catalytic glutamate converted into other amino acids (such as aspartate and alanine), thus providing various amino acid donors for grain protein synthesis and metabolism (Lea, 1999; Yamagata and Tanaka, 1986).

Hence, with the objective of investigating the effect of different temperatures on rice grain protein and key enzymes activity involved in nitrogen metabolism in grain, this study was conducted by in Guangdong province (major rice producing province in South China).

\section{Materials and methods}

\section{Experimental details}

Seeds of two rice cultivars, i.e., Basmati385 and Xiangyaxiangzhan which are widely grown in South China were used in this study. Pot experiment between March and July in 2018 was conducted at Experimental Research Farm, College of Agriculture, South China

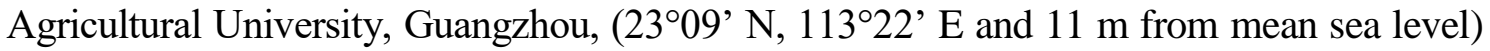
China. Before sowing, seeds of both cultivars were soaked in water for $24 \mathrm{~h}$ at room 
temperature and germinated at $37^{\circ} \mathrm{C}$, shade dried and the germinated seeds were sown in PVC trays for nursery raising, then, PVC trays were placed in puddled field and covered with a plastic sheet. Seedlings were transplanted into soil containing plastic pots $(31 \mathrm{~cm}$ in diameter and $29 \mathrm{~cm}$ in height) in April. The experimental soil containing 24.56\% organic matter content, $1.443 \%$ total nitrogen; $0.927 \%$ total phosphorous, $18.220 \%$ total potassium. At heading stage, the pots were translated into phytotron and the treatment description is as below:

T1: $33{ }^{\circ} \mathrm{C}$ days and $28^{\circ} \mathrm{C}$ nights, under $1300 \mathrm{X}$ yellow light intensity and $75 \%$ humidity T2: $28^{\circ} \mathrm{C}$ days and $22{ }^{\circ} \mathrm{C}$ nights, under $1300 \mathrm{X}$ yellow light intensity and $75 \%$ humidity T3: $23{ }^{\circ} \mathrm{C}$ days and $17^{\circ} \mathrm{C}$ nights, under $1300 \mathrm{X}$ yellow light intensity and $75 \%$ humidity

\section{Sampling collection}

The fresh grains were sampled from the rice after 7, 14 and 21 days heading stage and Maturity stage ( $\mathrm{d} \mathrm{AH}=$ day after heading stage, Maturity stage at $28 \mathrm{~d} \mathrm{AH}$ ). Samples were immediately stored at $-80^{\circ} \mathrm{C}$ for biochemical analyses.

\section{Determination of soluble protein}

Grain protein contents were measured according to the method of Bradford (1976) which using G-250 and the absorbance was read at $595 \mathrm{~nm}$ and the content of soluble protein was expressed as $\mu \mathrm{g} \mathrm{g}^{-1} \mathrm{FW}$. The measurements were repeated in triplicate and averaged.

\section{Determination of (glutamine synthetase) GS, glutamate synthetase (GOGAT), glutamate dehydrogenase (GDH), GOT and GPT}

For extraction of enzymes, grain tissue was homogenized with $10 \mathrm{mM}$ Tris- $\mathrm{HCl}$ buffer ( $\mathrm{pH}$ 7.6, containing $1 \mathrm{mM} \mathrm{MgCl}, 1 \mathrm{mM}$ EDTA and $1 \mathrm{mM}$ 2-mercaptoethanol) in a chilled pestle and mortar. After centrifuging at $15000 \mathrm{~g}$ at $30 \mathrm{~min}$, the whole extraction procedures were carried out at $4{ }^{\circ} \mathrm{C}$.

GS activity was assayed according to the method devised by Oaks (Oaks and Boesel, 1980). Reaction was started by adding the enzyme extract and stopping by adding $2.5 \%$ $(\mathrm{w} / \mathrm{v}) \mathrm{FeCl}_{3}$ and $5 \%(\mathrm{w} / \mathrm{v})$ trichloroacetic acid. GS activity was expressed as $1 \mu \mathrm{mol} \mathrm{L-}$ glutamate $\gamma$-monohydroxamatc formed per min. GOGAT activity was assayed by the method of Singh and Srivastava (2010). The absorbance decrease was recorded for $3 \mathrm{~min}$ at $340 \mathrm{~nm}$ and the activity was defined as $1 \mathrm{OD}_{340}$ per min while the GDH activity was determined according to the method of Kanamori et al. (2010). Reaction was activated by adding the enzyme extract and the decrease in absorbance was recorded for $3 \mathrm{~min}$ at $340 \mathrm{~nm}$ while enzyme activity was define as a decrease of $1 \mathrm{OD}_{340}$ per min. The activities of GOT and GPT was measured by the method of Cao et al. (2012) and expressed as $1 \mu \mathrm{mol}$ acetylformic acid formed in $1 \mathrm{~h} / \mathrm{g}$ of plants. The measurements were repeated in triplicate and averaged.

\section{Measurement of yield and grain quality}

Rice from six randomly selected pots from each treatment were harvested at Maturity stage. Then threshed manually and sun dried (adjusted to $\sim 15 \%$ moisture contents) to get the grain yield per pot and expressed in grams per hill $\left(\mathrm{g} \mathrm{hill}^{-1}\right)$ while an Infratec- 
1241 grain analyzer (FOSS-TECATOR) was used to measure the grain amylose and protein contents. The measurements were repeated in triplicate and averaged.

\section{Statistical analyses}

Data was analyzed using statistical software 'Statistix 8.1' (Analytical Software, Tallahassee, FL, USA) while differences amongst means were separated by using Fisher's Least Significant Difference (LSD) test at 5\% probability level. 'Origin 8.1' (OriginLab Co., Northampton, MA, USA) was used for graphical representation.

\section{Results}

\section{Soluble protein in grain}

At grain filling stage, different temperatures affected soluble protein significantly (Fig. 1). For Basmati385, highest protein content in grain was recorded in Te3 at $14 \mathrm{~d}$ $\mathrm{AH}, 21 \mathrm{~d} \mathrm{AH}$ and Maturity while Te1 was remained at the lowest level in whole filling stage. Moreover, there was no significant difference between Te 2 and Te3 at both $14 \mathrm{~d}$ $\mathrm{AH}$ and Maturity. For Xiangyaxiangzhan, Te1 and Te2 had no significant difference in grain protein content at Maturity while the highest content was recorded in Te3. Furthermore, the trend of soluble protein was observed as: Te $3>\mathrm{Te} 2>\mathrm{Te} 1$ at $7 \mathrm{~d} \mathrm{AH}$, $14 \mathrm{~d} \mathrm{AH}$ and $21 \mathrm{~d} \mathrm{AH}$ in whole filling stage.
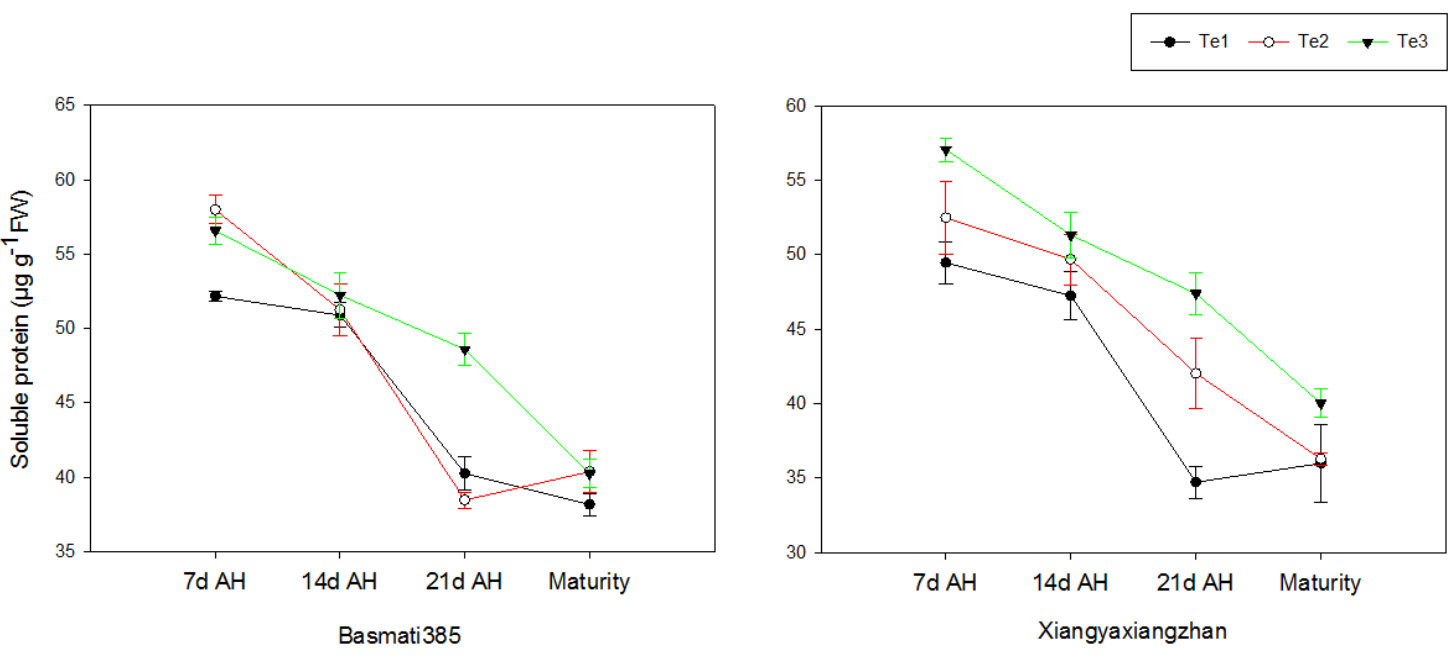

Figure 1. Effect of different temperature at filling stage on soluble protein in grain ( $d A H=$ days after heading, FW mean fresh weigh, the same as below)

\section{GS and GOGAT activities}

As shown in Table 1, For Basmati385, there was no significant difference in both GS and GOGAT activities at $7 \mathrm{~d}$ AH under the different temperature whilst at $14 \mathrm{~d} \mathrm{AH}$, the trend of GS was recorded as: Te3 > Te2 > Te1. The highest activity of GS at $21 \mathrm{~d} \mathrm{AH}$ was recorded in $\mathrm{Te} 2$ while there was no significant difference in GS activity at Maturity. Moreover, the highest GOGAT activity was recorded in Te3 at Maturity whilst at $21 \mathrm{~d} \mathrm{AH}$, the trend of GOGAT activity was recorded as: Te1 > Te2 > Te3. Similar result was also observed in Xiangxiangzhan. At $7 \mathrm{~d}$ AH and $14 \mathrm{~d} \mathrm{AH}$, there was 
no significant difference among different controlled temperature treatments in GS activity. However, at $21 \mathrm{~d} \mathrm{AH}$ and Maturity, the lowest GS activity was recorded in Te1 while there was no significant difference between Te2 and Te3. Furthermore, there was no significant difference among different treatments in GOGAT activity at Maturity.

Table 1. Effect of different temperature at filling stage on activities of GS and GOGAT

\begin{tabular}{c|c|c|c|c|c|c|c|c|c}
\hline \multirow{2}{*}{ Cultivar } & \multirow{2}{*}{ Treatment } & \multicolumn{4}{|c|}{ GS activity $\left(\Delta\right.$ OD g $^{-1}$ min-1 } & \multicolumn{4}{c}{ GOGAT activity $\left(\boldsymbol{\mu m o l ~}^{-1} \mathbf{m i n}^{-1}\right)$} \\
\cline { 3 - 9 } & & $\mathbf{7 d ~ A H}$ & $\mathbf{1 4 d} \mathbf{A H}$ & $\mathbf{2 1 d} \mathbf{A H}$ & Maturity & $\mathbf{7 d ~ A H}$ & $\mathbf{1 4 d}$ AH & $\mathbf{2 1 d}$ AH & Maturity \\
\hline \multirow{3}{*}{ Basmati385 } & $\mathrm{Te} 1$ & $0.27 \pm 0.00 \mathrm{a}$ & $0.18 \pm 0.01 \mathrm{~b}$ & $0.15 \pm 0.01 \mathrm{~b}$ & $0.12 \pm 0.01 \mathrm{a}$ & $0.15 \pm 0.00 \mathrm{a}$ & $0.23 \pm 0.01 \mathrm{a}$ & $0.19 \pm 0.01 \mathrm{a}$ & $0.19 \pm 0.00 \mathrm{~b}$ \\
& $\mathrm{Te} 2$ & $0.31 \pm 0.02 \mathrm{a}$ & $0.21 \pm 0.02 \mathrm{ab}$ & $0.18 \pm 0.01 \mathrm{a}$ & $0.12 \pm 0.01 \mathrm{a}$ & $0.17 \pm 0.00 \mathrm{a}$ & $0.20 \pm 0.01 \mathrm{~b}$ & $0.19 \pm 0.01 \mathrm{ab}$ & $0.18 \pm 0.01 \mathrm{~b}$ \\
& $\mathrm{Te} 3$ & $0.30 \pm 0.02 \mathrm{a}$ & $0.24 \pm 0.02 \mathrm{a}$ & $0.17 \pm 0.02 \mathrm{~b}$ & $0.12 \pm 0.01 \mathrm{a}$ & $0.16 \pm 0.01 \mathrm{a}$ & $0.20 \pm 0.01 \mathrm{~b}$ & $0.16 \pm 0.00 \mathrm{~b}$ & $0.23 \pm 0.01 \mathrm{a}$ \\
\hline \multirow{3}{*}{ Xiangyaxiangzhan } & $\mathrm{Te} 1$ & $0.27 \pm 0.04 \mathrm{a}$ & $0.22 \pm 0.00 \mathrm{a}$ & $0.06 \pm 0.01 \mathrm{~b}$ & $0.05 \pm 0.00 \mathrm{~b}$ & $0.19 \pm 0.00 \mathrm{~b}$ & $0.18 \pm 0.00 \mathrm{a}$ & $0.23 \pm 0.00 \mathrm{a}$ & $0.18 \pm 0.01 \mathrm{a}$ \\
& $\mathrm{Te} 2$ & $0.24 \pm 0.01 \mathrm{a}$ & $0.22 \pm 0.01 \mathrm{a}$ & $0.13 \pm 0.03 \mathrm{a}$ & $0.09 \pm 0.01 \mathrm{a}$ & $0.19 \pm 0.00 \mathrm{~b}$ & $0.18 \pm 0.00 \mathrm{~b}$ & $0.21 \pm 0.01 \mathrm{~b}$ & $0.19 \pm 0.01 \mathrm{a}$ \\
& $\mathrm{Te} 3$ & $0.26 \pm 0.03 \mathrm{a}$ & $0.24 \pm 0.01 \mathrm{a}$ & $0.12 \pm 0.02 \mathrm{a}$ & $0.10 \pm 0.02 \mathrm{a}$ & $0.22 \pm 0.00 \mathrm{a}$ & $0.18 \pm 0.01 \mathrm{~b}$ & $0.17 \pm 0.00 \mathrm{c}$ & $0.19 \pm 0.01 \mathrm{a}$ \\
\hline
\end{tabular}

Means in the same column followed by different lower case letters for the same variety differ significantly at $\mathrm{P}<0.05$ by T-test, the same as below

\section{GDH activities}

Different temperatures affected GDH activity significantly at filling stage (Fig. 2). For Basmati385, the highest activity was recorded in Te2 at both $7 \mathrm{~d} \mathrm{AH}$ and $21 \mathrm{~d} \mathrm{AH}$ whilst at $14 \mathrm{~d} \mathrm{AH}$ and Maturity, activity in Te2 was remained in the lowest level. For Xiangyaxiangzhan, at $7 \mathrm{~d} \mathrm{AH}$, the trend of GDH activity was recorded as: $\mathrm{Te} 3>\mathrm{Te} 2>$ $\mathrm{Te} 1$ and similar results were also found at $21 \mathrm{~d} \mathrm{AH}$ and Maturity.
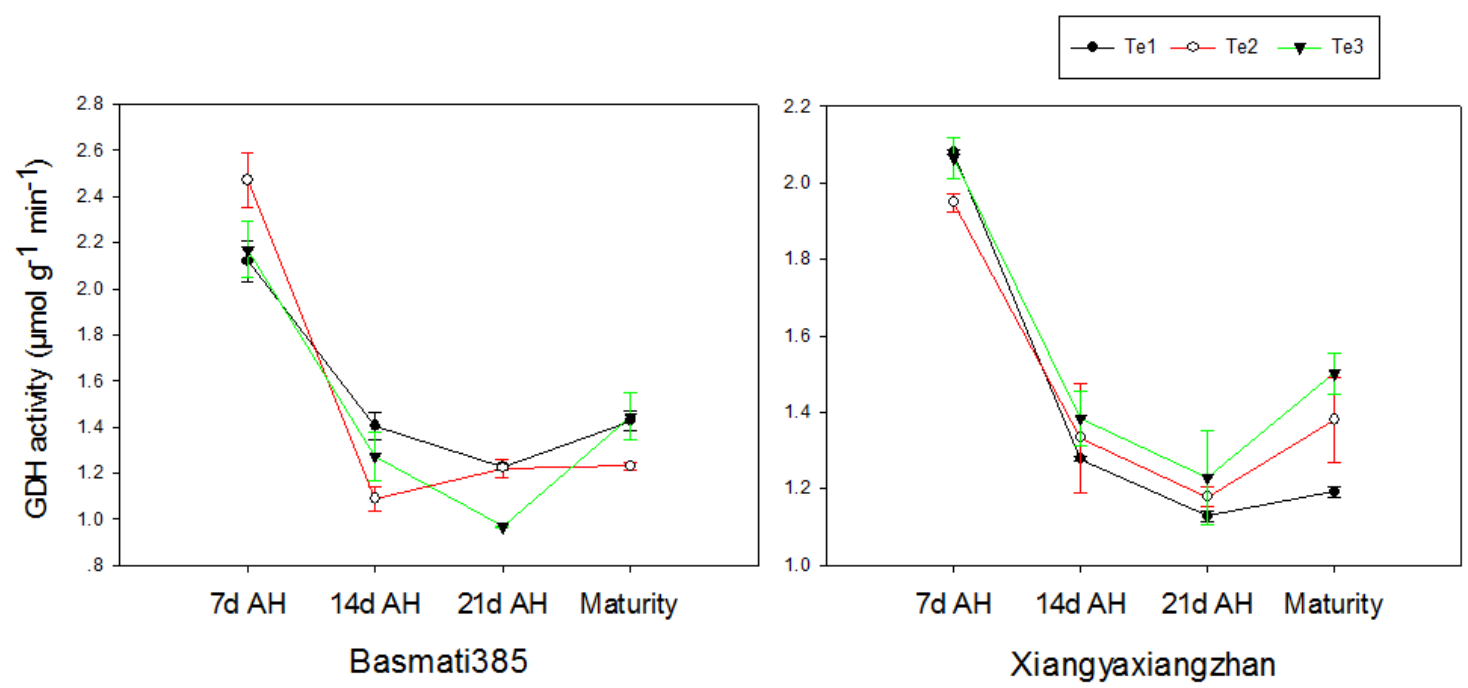

Figure 2. Effect of different temperature at filling stage on activity of GDH

\section{GOT and GPT activities}

As showed in Figure 3, for Basmati385, compared with Te1, 8.37, 7.11, 10.69 and 4.17\% higher GOT activity were recorded in Te2 at $7 \mathrm{~d} \mathrm{AH}, 14 \mathrm{~d} \mathrm{AH}, 21 \mathrm{~d} \mathrm{AH}$ and Maturity respectively. There was no significant differences between $\mathrm{Te} 2$ and $\mathrm{Te} 3$ at 
$14 \mathrm{~d}$ AH and $21 \mathrm{~d}$ AH. The trend of GOT activity was recorded as: Te3 $>\mathrm{Te} 2>\mathrm{Te} 1$. Moreover, at $14 \mathrm{~d} \mathrm{AH}, 21 \mathrm{~d} \mathrm{AH}$ and Maturity, the trend of GPT activity was recorded as $\mathrm{Te} 3>\mathrm{Te} 2>\mathrm{Te} 1$. For Xiangyaxiangzhan, there was no significant difference in GOT activity under different controlled temperature conditions at $7 \mathrm{~d} \mathrm{AH}$ whilst at $21 \mathrm{~d} \mathrm{AH}$ and Maturity, the trend of GOT activity was recorded as: Te3 $>\mathrm{Te} 2>\mathrm{Te} 1$. Meanwhile, compared with Te1, 2.75, 4.08, 0.62 and $3.67 \%$ higher GOT activity were recorded in $\mathrm{Te} 2$ at $7 \mathrm{~d} \mathrm{AH}, 14 \mathrm{~d} \mathrm{AH}, 21 \mathrm{~d} \mathrm{AH}$ and Maturity respectively. 1.38 and $5.05 \%$ higher activity also were recorded in $\mathrm{Te} 3$ at $21 \mathrm{~d} \mathrm{AH}$ and maturity. Furthermore, the trend of GPT activity at both $21 \mathrm{~d}$ AH and Maturity was recorded as: Te3 $>\mathrm{Te} 2>\mathrm{Te} 1$.
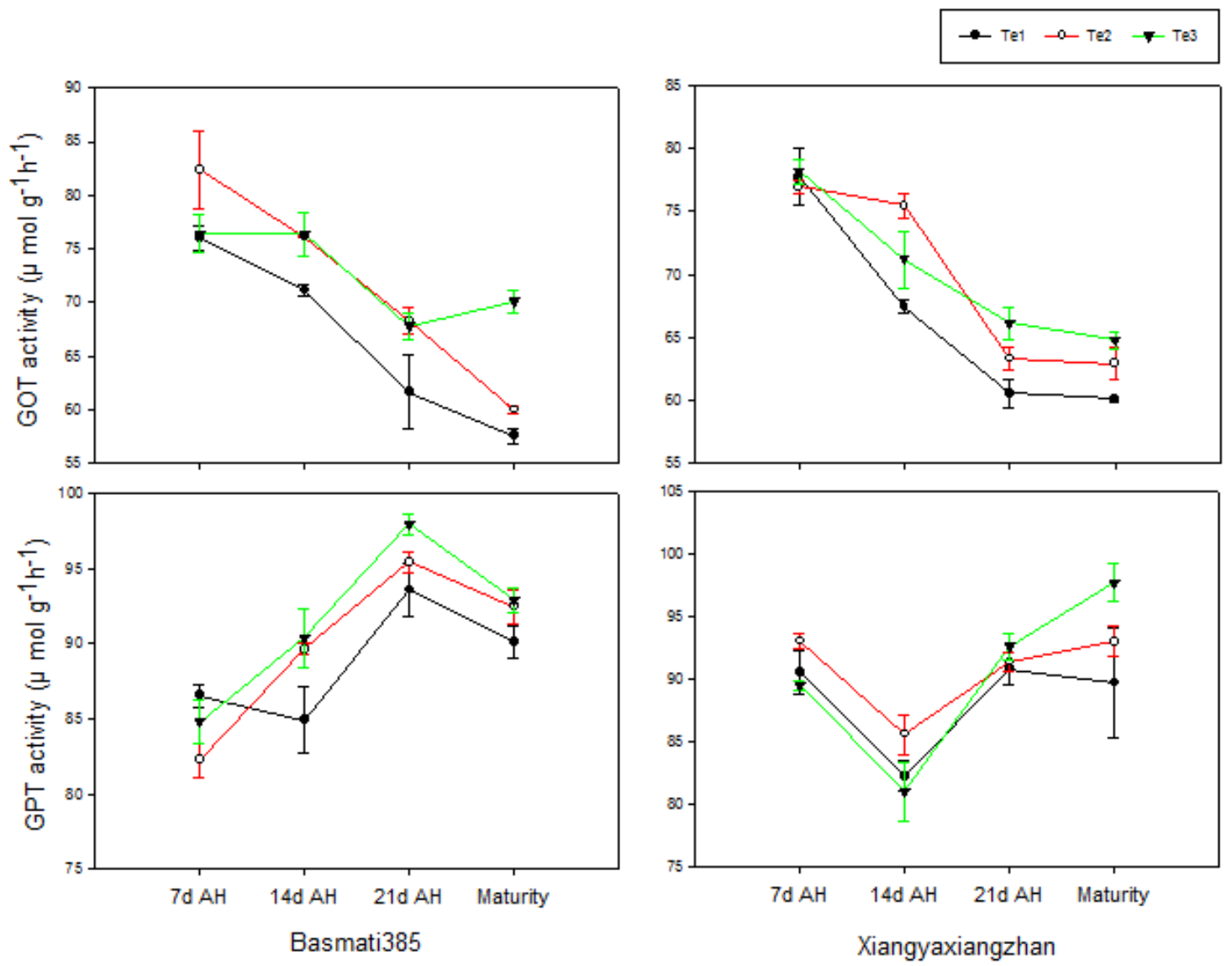

Figure 3. Effect of different temperature at filling stage on activities of GOT and GPT

\section{Yield and grain quality}

There were significant differences in rice yield and grain quality in different controlled temperatures at filling stage (Table 2). For example, 16.86 and $17.02 \%$ higher crude protein was recorded in $\mathrm{Te} 2$ and $\mathrm{Te} 3$ by comparing with $\mathrm{Te} 1$ in Basmati385. Similar result was also found in Xiangyaxiangzhan, 5.41 and $6.89 \%$ higher crude protein were recorded in Te 2 and Te3. For yield, the highest yield was recorded in $\mathrm{Te} 2$ while there was no significant difference between Te1 and Te3 in Basmati385 whilst in Xiangyaxiangzhan, the lowest yield was recorded in Te3 while there was no significant difference between Te1 and Te2. Moreover, the trend of Akali was recorded as: $\mathrm{Te} 3>\mathrm{Te} 2>\mathrm{Te} 1$ in both Basmati385 and Xiangyaxiangzhan. 
Table 2. Effect of different temperature at filling stage on yield and grain quality

\begin{tabular}{c|c|c|c|c|c|c}
\hline Cultivar & Treatments & $\begin{array}{c}\text { Crude } \\
\text { protein (\%) }\end{array}$ & $\begin{array}{c}\text { Amylose } \\
\text { content (\%) }\end{array}$ & Akali & Moisture (\%) & $\begin{array}{c}\text { Yield } \\
\left.\text { (g hill } \mathbf{- 1}^{\mathbf{1}}\right)\end{array}$ \\
\hline \multirow{3}{*}{ Basmati385 } & $\mathrm{Te} 1$ & $6.17 \pm 0.03 \mathrm{c}$ & $20.70 \pm 0.06 \mathrm{a}$ & $4.27 \pm 0.03 \mathrm{c}$ & $13.9 \pm 0.01 \mathrm{a}$ & $10.01 \pm 0.13 \mathrm{~b}$ \\
& $\mathrm{Te} 2$ & $7.21 \pm 0.03 \mathrm{a}$ & $19.43 \pm 0.46 \mathrm{~b}$ & $6.10 \pm 0.06 \mathrm{~b}$ & $13.73 \pm 0.03 \mathrm{~b}$ & $11.31 \pm 0.71 \mathrm{a}$ \\
& $\mathrm{Te} 3$ & $7.02 \pm 0.03 \mathrm{~b}$ & $19.43 \pm 0.34 \mathrm{~b}$ & $6.57 \pm 0.07 \mathrm{a}$ & $13.8 \pm 0.02 \mathrm{~b}$ & $9.89 \pm 0.13 \mathrm{~b}$ \\
\hline \multirow{3}{*}{ Xiangyaxiangzhan } & $\mathrm{Te} 1$ & $8.13 \pm 0.07 \mathrm{~b}$ & $17.47 \pm 0.35 \mathrm{~b}$ & $5.97 \pm 0.03 \mathrm{~b}$ & $13.73 \pm 0.03 \mathrm{a}$ & $11.01 \pm 0.47 \mathrm{ab}$ \\
& $\mathrm{Te} 2$ & $8.57 \pm 0.03 \mathrm{a}$ & $18.67 \pm 0.12 \mathrm{a}$ & $6.63 \pm 0.03 \mathrm{a}$ & $13.43 \pm 0.03 \mathrm{~b}$ & $11.55 \pm 0.30 \mathrm{a}$ \\
& $\mathrm{Te} 3$ & $8.50 \pm 0.01 \mathrm{ab}$ & $18.87 \pm 0.15 \mathrm{a}$ & $6.73 \pm 0.07 \mathrm{a}$ & $13.67 \pm 0.03 \mathrm{a}$ & $10.46 \pm 0.30 \mathrm{~b}$ \\
\hline
\end{tabular}

\section{Correlation analysis}

As shown in Table 3, the activities of GDH, GS and GOT all had significant positive correlation with soluble protein content. However, there exited a negative correlation between GPT activity and soluble protein. A significant negative correlation between GPT and GOT was also observed. Moreover, both GS and GOT had a significant positive correlation with GDH. There exited a significant positive correlation between GOT and GS while GPT had a significant negative correlation with GS.

Table 3. Relationship between soluble protein content and some key enzymes in nitrogen metabolism

\begin{tabular}{c|c|c|c|c|c}
\hline Parameters & Soluble protein & GOGAT & GDH & GS & GPT \\
\hline GOGAT & -0.2131 & & & & \\
GDH & $0.6181^{* *}$ & -0.2033 & & & \\
GS & $0.9065^{* *}$ & -0.2755 & $0.6986^{* *}$ & & \\
GPT & $-0.5282^{* *}$ & 0.1138 & -0.3868 & $-0.5544 * *$ & \\
GOT & $0.8891^{* *}$ & -0.0991 & $0.6766^{* *}$ & $0.8899 * *$ & $-0.4171^{*}$ \\
\hline
\end{tabular}

Significant correlations at $* \mathrm{P}<0.05$ and $* * \mathrm{P}<0.01$

\section{Discussion}

The forming process of rice quality is the metabolism of carbon, nitrogen and fat while the synthesis and transport of photosynthetic products, grain filling dynamics and key enzyme activities are closely related to rice quality (Mo et al., 2014; Cheng et al., 2003; Lin et al., 2005). Protein is the second largest storage substance in rice grain after starch and its content is not only an important index to determine the quality of rice nutrient, but also affects the appearance, processing and food quality of rice to a certain extent (Tsukaguchi et al., 2016). As one of factors which had substantial influence on grain quality, the effect of nitrogen fertilizer application on grain protein had been studied in a lot of researches (Pirmoradian et al., 2004; Samonte et al., 2006), and now, it is generally considered that grain protein content increased with added $\mathrm{N}$ level. In 1972, the study of Datta et al. (1972) showed that the grain protein content of several rice varieties was significantly higher when $150 \mathrm{~kg} \mathrm{ha}^{-1}$ nitrogen fertilizer was applied half at planting and anther half was applied at heading than all nitrogen was applied at 
planting. Furthermore, a previous research showed significant differences in the four kinds of protein and total protein content in grain among the 5 nitrogen treatments and demonstrated that concentrations in grain protein increased with the increased $\mathrm{N}$ level (Ning et al., 2009). However, the absorption and utilization of nitrogen by various plants must be completed through a series of reactions and transformations involving nitrogen metabolic enzymes (Surabhi et al., 2008; Nie et al., 2003). For example, the ammonium nitrogen converts into glutamic acid by GS-GOGAT pathway or GDH pathway, then, GOT and GPT catalyze glutamate conversion to aspartate and alanine respectively and finally provided amino acid donors for synthesis and metabolism of grain protein (Cao et al., 2012). Thus, the activities of some enzymes in nitrogen metabolism are important for synthesis and accumulation of grain protein and it could be an entry point to study how the environment and management affect the grain protein and there was no much investigation about the effect of temperature on grain protein or how temperature affected the protein synthesis. Therefore, our research has its originality in rice production.

In this study, we observed that the crude protein and soluble protein in Te1 was remained at the lowest level. Compared with Te1, the lower temperature conditions including $\mathrm{Te} 2$ and $\mathrm{Te} 3$ enhanced the protein content in grain while there was no significant difference between $\mathrm{Te} 2$ and $\mathrm{Te} 3$ in both soluble protein and crude protein. This discovery meant that the temperature from $23 / 17{ }^{\circ} \mathrm{C}$ to $28 / 22^{\circ} \mathrm{C}$ might be suitable for grain protein synthesis. A similar result also have been reported in 1997, the study of Meng and Zhou (1997) showed that lower temperature at grain filling stage was good for the synthesis and accumulation of grain protein because the protein content in 18 and $25^{\circ} \mathrm{C}$ treatments were significant higher than 27 and $30^{\circ} \mathrm{C}$. Our discovery indicated that an appropriate low temperature was able to promote the synthesis of grain protein and it might because the key enzymes of nitrogen metabolism such as GOT, GS and GDH had higher activity under lower temperature.

Correlation analysis showed that the soluble protein had a significant positive correlation with GS activity. This discovery agreed with the research of Jin et al. (2007) which revealed that the duration from $15 \mathrm{~d}$ to $20 \mathrm{~d}$ after heading was the break through stage at which the correlative nature varied between the activity of GS in grain and taste meter value and RNA proper ties. Furthermore, we also observed that the activity of GDH in Xiangyaxiangzhan increased with the decease of temperature at middle and later phase of filing stage. GDH is a one of the few enzymes which is able to release amino nitrogen from amino acids in order to give keto-acid and $\mathrm{NH}_{3}$ that could be separately recycled to be used for respiration and amide formation, respectively (Miflin and Habash, 2002). It is generally believed that GS-GOGAT cycle is the main way of ammonium assimilation in higher plants since 1974 (Lea and Miflin 1974). However, in this study, the positive correlation between protein and GDH activity might imply that $\mathrm{GDH}$ is restriction enzyme in grain for protein synthesis just like GS. Moreover, compared with Te1, Te2 and Te3 improved the activities of GOT and GPT in later phase of filling stage. As the key enzymes in nitrogen metabolism, GOT and GPT activities affect the contents of protein and amino acid significant (Sun et al., 2009). There also exited a significant positive correlation between GOT and protein in this study. Therefore, the increased grain protein content may be the result of the combined effect of enhanced GDH and GOT activities. The process and mechanism of synthesis from amino acids to proteins in rice grain have not been clarified. From our discovery, we considered that lower temperature condition within an appropriate range could 
improve the activities of some key enzymes in nitrogen metabolism and thus enhanced biosynthesis from amino acids to protein and finally increased the grain protein content. In order to reveal the further mechanism, much work should be done at molecular level.

In addition, the effect of temperature on rice yield and quality had been studied by many researchers (Shimono et al., 2005; Li et al., 2011; Ishimaru et al., 2009). Fourré and Lhoest (1989) found that cells of callus derived from seed embryos of Oryza sativa which was exposed to heat shock depressed normal synthesis of protein while synthesis of specific proteins was improved. A previous reported demonstrated that a rise in temperature above $35^{\circ} \mathrm{C}$ would pollen sterility and affect fertilization severely (Kumar et al., 2015). The study of Thussagunpanit et al. (2015) also showed that heat stress could decrease the rice yield greatly by influencing photosynthetic efficiency. In present study, there were also some differences among different controlled temperature conditions. The highest yield was recorded in Te2 in both Basmati385 and Xiangyaxiangzhan while Te3 was significant lower than Te2. Thus, the optimum temperature at filling stage for Basmati385 and Xiangyaxiangzhan was consider as Te2 because it enhance the grain protein content significantly compared with Te1 and had the highest yield. The result of this research also reminded that in the rice production, we could take some strategies such as delayed sowing date to appropriately lower the temperature at filling stage so the grain protein content could be improved.

\section{Conclusion}

In conclusion, compared with $\mathrm{Te} 1, \mathrm{Te} 2$ and $\mathrm{Te} 3$ had higher activity of key enzymes in nitrogen metabolism in grain at filling stage. Furthermore, the highest protein content was recorded in Te2. Thus, the temperatures among $23 \sim 28{ }^{\circ} \mathrm{C}$ at filling stage might be more suitable for rice protein biosynthesis. Much work should be done at molecular and physiological level.

Acknowledgements. This study was funded by National Natural Science Foundation of China (31271646), The World Bank Loan Agricultural Pollution Control Project in Guangdong (07241510A08N3684) and (2017LM1098). The authors declare no conflicts of interest.

\section{REFERENCES}

[1] Alam, M. Z. (2012): Growth, Yield and Nitrogen Utilization of Barley. - Lambert Academic Publishing, Riga.

[2] Bradford, M. (1976): A rapid and sensitive method for quantitation of microgram quantities of protein utilizing the principle of protein dye binding. - Analytical Biochemistry 72: 248-254.

[3] Cheng, W., Zhang, G., Zhao, G., Yao, H., Xu, H. (2003): Variation in rice quality of different cultivars and grain positions as affected by water management. - Field Crops Research 80: 245-252.

[4] Datta, S. K. D., Obcemea, W. N., Jana, R. K. (1972): Protein content of rice grain as affected by nitrogen fertilizer and some triazines and substituted ureas. - Agronomy Journal 64: 785-788.

[5] Fourré, J. L., Lhoest, J. (1989): Protein synthesis and modification by heat in rice cell culture. - Plant Science 61: 69-74.

[6] Ishimaru, T., Horigane, A. K., Ida, M., Iwasawa, N., Sanoh, Y. A., Nakazono, M., Nishizawa, N. K., Masumura, T., Kondo, M., Yoshida, M. (2009): Formation of grain 
chalkiness and changes in water distribution in developing rice caryopses grown under high-temperature stress. - Journal of Cereal Science 50: 166-174.

[7] Jin, Z. X., Qian, C. R., Yang, J., Liu, H. Y. (2007): Changes of activity of glutamine synthetase during grain filling and its influence on rice grain quality. - Chinese Journal of Rice Science 21: 103-106.

[8] Kanamori, T., Konishi, S., Takahashi, E. (2010): Inducible formation of glutamate dehydrogenase in rice plant roots by the addition of ammonia to the media. - Physiologia Plantarum 26: 1-6.

[9] Kim, J., Shon, J., Lee, C. K., Yang, W., Yoon, Y., Yang, W. H., Kim, Y. G., Lee, B. W. (2011): Relationship between grain filling duration and leaf senescence of temperate rice under high temperature. - Field Crops Research 122: 207-213.

[10] Kong, L., Ashraf, U., Cheng, S., Rao, G., Mo, Z., Tian, H., Pan, S., Tang, X. (2017): Short-term water management at early filling stage improves early-season rice performance under high temperature stress in South China. - European Journal of Agronomy 90: 117-126.

[11] Kumar, N., Kumar, N., Shukla, A., Shankhdhar, S. C., Shankhdhar, D. (2015): Impact of terminal heat stress on pollen viability and yield attributes of rice (Oryza sativa L.). Cereal Research Communications 43: 1-11.

[12] Lea, P. J., Miflin, B. J. (1974): Alternative route for nitrogen assimilation in higher plants. - Nature 251: 614-616.

[13] Li, H., Chen, Z., Hu, M., Wang, Z., Hua, H., Yin, C., Zeng, H. (2011): Different effects of night versus day high temperature on rice quality and accumulation profiling of rice grain proteins during grain filling. - Plant Cell Reports 30: 1641-1659.

[14] Lin, C. J., Li, C. Y., Lin, S. K., Yang, F. H., Huang, J. J., Liu, Y. H., Lur, H. S. (2010): Influence of high temperature during grain filling on the accumulation of storage proteins and grain quality in rice (Oryza sativa L.). - Journal of Agricultural, \& Food Chemistry 58: 10545-10552.

[15] Lin, S., Chang, M. Y., Lur, H. (2005): Proteomic analysis of the expression of proteins related to rice quality during caryopsis development and the effect of high temperature on expression. - Proteomics 5: 2140-2156.

[16] Mahajan, G., Sekhon, N. K., Singh, N., Kaur, R., Sidhu, A. S. (2010): Yield and nitrogenuse efficiency of aromatic rice cultivars in response to nitrogen fertilizer. - Journal of New Seeds 11: 356-368.

[17] Meng, Y., Zhou, Z. (1997): Relationship between rice grain quality and temperature during seed setting period. - Chinese Journal of Rice Science 11(1): 51-54.

[18] Miflin, B. J., Habash, D. Z. (2002): Carbon and nitrogen relationships and signalling. The role of glutamine synthetase and glutamate dehydrogenase in nitrogen assimilation and possibilities for improvement in the nitrogen utilization of crops. - J. Exp. Bot. 53: 979.

[19] Mo, Z. W., Wu, J. X., Tian, J. Y., Lin, Q. S., Jiang, Y. J., Duan, M. Y., Pan, S. G., Tian, H., Tang, X. R. (2014): Comparison of rice yield, grain quality and some physiological parameters as affected by cultivation techniques. - Crop Protection Newsletter 39: 45-50.

[20] Nguyen, N. V. (2005): Global Climate Changes and Rice Food Security. - International Rice Commission Newsletter 54: 24-30.

[21] Nie, J., Xiao, J., Dai, P., Zheng, S. (2003): Effect of controlled release nitrogen fertilizer on key enzymes activities of nitrogen metabolism and protein contents in brown rice. Journal of Hunan Agricultural University.

[22] Ning, H., Liu, Z., Wang, Q., Lin, Z., Chen, S., Li, G., Wang, S., Ding, Y. (2009): Effect of nitrogen fertilizer application on grain phytic acid and protein concentrations in japonica rice and its variations with genotypes. - Journal of Cereal Science 50: 49-55.

[23] Oaks, A., Boesel, I. L. (1980): Enzymes of nitrogen assimilation in maize roots. - Planta 148: 477-484.

[24] Pirmoradian, N., Sepaskhah, A. R., Maftoun, M. (2004): Deficit irrigation and nitrogen effects on nitrogen-use efficiency and grain protein of rice. - Agronomie 24: 143-153. 
[25] Shi, P., Tang, L., Wang, L., Sun, T., Liu, L., Cao, W., Zhu, Y. (2015): Post-heading heat stress in rice of South China during 1981-2010. - Plos One 10: e0130642.

[26] Shimono, H., Hasegawa, T., Moriyama, M., Fujimura, S., Nagata, T. (2005): Modeling spikelet sterility induced by low temperature in rice. - Agronomy Journal 97: 1524-1536.

[27] Singh, R. P., Srivastava, H. S. (2010): Increase in glutamate synthase (NADH) activity in maize seedlings in response to nitrate and ammonium nitrogen. - Physiologia Plantarum 66: 413-416.

[28] Sun, Y. J., Sun, Y. Y., Xu-Yi, L. I., Guo, X., Jun, M. A. (2009): Relationship of nitrogen utilization and activities of key enzymes involved in nitrogen metabolism in rice under water-nitrogen interaction. - Acta Agronomica Sinica 35: 2055-2063.

[29] Surabhi, G. K., Reddy, A. M., Kumari, G. J., Sudhakar, C. (2008): Modulation of key enzymes of nitrogen metabolism in two genotypes of mulberry (Morus alba L.) with differential sensitivity to salt stress. Environ Exp Bot. - Environmental \& Experimental Botany 64: 171-179.

[30] Thussagunpanit, J., Jutamanee, K., Sonjaroon, W., Kaveeta, L., Chai-Arree, W., Pankean, P., Suksamrarn, A. (2015): Effects of brassinosteroid and brassinosteroid mimic on photosynthetic efficiency and rice yield under heat stress. - Photosynthetica 53: 312-320.

[31] Tsukaguchi, T., Nitta, S., Matsuno, Y. (2016): Cultivar differences in the grain protein accumulation ability in rice (Oryza sativa L.). - Field Crops Research 192: 110-117.

[32] Umemoto, T., Terashima, K., Nakamura, Y., Satoh, H. (2015): Differences in amylopectin structure between two rice varieties in relation to the effects of temperature during grain-filling. - Starch - Stärke 51: 58-62.

[33] Yamagata, H., Tanaka, K. (1986): The site of synthesis and accumulation of rice storage proteins. - Plant and Cell Physiology 205: 135-145.

[34] Yamakawa, H., Hakata, M. (2010): Atlas of rice grain filling-related metabolism under high temperature: joint analysis of metabolome and transcriptome demonstrated inhibition of starch accumulation and induction of amino acid accumulation. - Plant \& Cell Physiology 51: 795-809.

[35] Yamakawa, H., Hirose, T., Kuroda, M., Yamaguchi, T. (2007): Comprehensive expression profiling of rice grain filling-related genes under high temperature using DNA microarray. - Plant Physiology 144: 258-277.

[36] Zhong, L. J., Cheng, F. M., Wen, X., Sun, Z. X., Zhang, G. P. (2010): The deterioration of eating and cooking quality caused by high temperature during grain filling in earlyseason Indica rice cultivars. - Journal of Agronomy \& Crop Science 191: 218-225.

\section{APPENDIX}

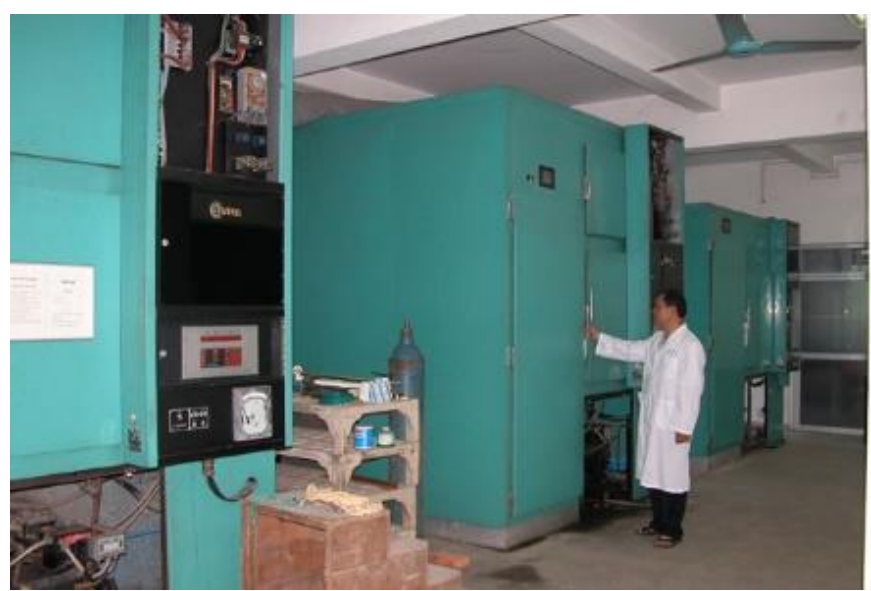

Equipment 